\title{
Identification of the major diacylglycerol acyltransferase mRNA in mouse adipocytes and macrophages
}

Heping Cao@

\begin{abstract}
Background: Triacylglycerols (TAGs) are the major form of energy storage in eukaryotes. Diacylglycerol acyltransferases (DGATs) catalyze the final and rate-limiting step of TAG biosynthesis. Mammalian DGATs are classified into DGAT1 and DGAT2 subfamilies. It was unclear which DGAT was the major isoform expressed in animal cells. The objective was to identify the major DGAT mRNA expressed in cultured mouse adipocytes and macrophages and compared it to that expressed in tung tree seeds.
\end{abstract}

Methods: qPCR evaluated DGAT mRNA levels in mouse 3T3-L1 adipocytes and RAW264.7 macrophages and tung tree seeds.

Results: TaqMan qPCR showed that DGAT2 mRNA levels were 10-30 fold higher than DGAT1 in adipocytes and macrophages, and DGAT mRNA levels in adipocytes were 50-100-fold higher than those in macrophages. In contrast, the anti-inflammatory tristetraprolin/zinc finger protein 36 (TTP/ZFP36) mRNA levels were 2-4-fold higher in macrophages than those in adipocytes and similar to DGAT1 in adipocytes but 100-fold higher than DGAT1 in macrophages. SYBR Green qPCR analyses confirmed TaqMan qPCR results. DGAT2 mRNA as the major DGAT mRNA in the mouse cells was similar to that in tung tree seeds where DGAT2 mRNA levels were 10-20-fold higher than DGAT1 or DGAT3.

Conclusion: The results demonstrated that DGAT2 mRNA was the major form of DGAT mRNA expressed in mouse adipocytes and macrophages and tung tree seeds.

Keywords: Adipocytes, Diacylglycerol acyltransferases, Gene expression, Macrophages, Tristetraprolin/Zinc finger protein 36, Tung tree

\section{Background}

Triacylglycerols (TAGs) are one of the major forms of energy storage in eukaryotes. They also serve as a source of fatty acids for membrane biogenesis and lead to obesity if overly accumulated in adipose tissues [1]. Diacylglycerol acyltransferases (DGATs) catalyze $s n$-1,2-diacylglycerol and a long-chain fatty acyl-CoA into TAG, the rate-limiting step of TAG biosynthesis [2]. DGAT deficiency results in less TAG accumulation [3-5]. DGAT knockout mice exhibit resistance to diet-induced obesity $[4,6]$, lack milk production [4] and link to a congenital diarrheal disorder [7]. More DGAT enzymatic activity increases TAG content in plants [8-14], animals [15-18] and yeast [19, 20]. Genetic studies

Correspondence: Heping.Cao@ars.usda.gov

U.S. Department of Agriculture, Agricultural Research Service, Southern Regional Research Center, New Orleans, LA 70124, USA have demonstrated that DGAT isoforms are unique in TAG biosynthesis in mice [5] and tung tree [21]. Understanding the specific functions of DGAT isoforms will help engineering plants and microbes with value-added properties and provide guidance for potential intervention and treatment of obesity and related diseases.

Although DGAT1 and DGAT2 perform similar biochemical reaction, they are encoded by distinctive gene families. Generally, DGATs are divided into DGAT1 and DGAT2 subfamilies [21, 22]. DGATs are integral membrane proteins $[21,23]$ with more than $40 \%$ of the total amino acid residues being hydrophobic [24]. We have classified over 100 DGAT protein sequences from 70 organisms into DGAT1 and DGAT2 subfamilies [24]. There are 41 and 16 completely conserved amino acid residues mostly located at the carboxyl termini of DGAT1s and DGAT2s,

(C) The Author(s). 2018 Open Access This article is distributed under the terms of the Creative Commons Attribution 4.0 International License (http://creativecommons.org/licenses/by/4.0/), which permits unrestricted use, distribution, and 
respectively [24]. DGATs have similar chemical properties and amino acid composition except that DGAT1s are $\sim 20 \mathrm{kDa}$ larger than DGAT2s [24]. Recent studies have shown that DGAT3s are present in tung tree (Vernicia fordii) [25], yeast (Rhodotorula glutinis) [26], Arabidopsis thaliana [22], Burning Bush (Euonymus alatus) [10], peanut (Arachis hypogaea) [27], a bifunctional DGAT in Acinetobacter calcoaceticus ADP1 [28], castor bean (Ricinus communis) and various other plant species. DGAT3s are different from DGAT1s and DGAT2s [25] because none of the completely conserved residues in DGAT1s (41 residues) and DGAT2s (16 residues) is aligned with DGAT3s [24, 25]. In addition, oil palm (Elaeis guineensis) genome has four closely related but differentially expressed DGATs (DGAT1, DGAT2, DGAT3 and WS/DGAT) and at least two members of each of the four DGAT groups are found by in silico analysis [29].

Currently, it is not clear which form of DGAT is the major isoform expressed in many mammalian cells. DGAT1 was shown to be highly expressed in mice intestine and plays a crucial role in TAG biosynthesis [30, 31]. In contrast, DGAT2 has been shown to be the major form of DGAT in tung tree seeds $[21,25]$. The objective of this study was to identify the major form of DGAT mRNA expressed in mammalian cells using cultured mouse 3 T3-L1 adipocytes and RAW264.7 macrophages and to compare it to DGATs expressed in tung tree seeds to gain insights into which is the major DGAT mRNA in three different types of cells from animal and plant origins (Fig. 1). TaqMan and SYBR Green quantitative real-time PCR (qPCR) assays evaluated mouse DGAT mRNA levels using ribosomal protein L32 (RPL32) gene as an internal reference [32-34]. The positive control of gene expression was using the anti-inflammatory tristetraprolin (TTP)/zinc finger protein 26 (ZFP36) expressed in both mouse 3 T3-L1 adipocytes and RAW264.7 macrophages [35-37]. DGATs of tung tree seeds were also analyzed for comparison. The results reported here conclusively demonstrated that DGAT2 mRNA was the major form of DGAT mRNA expressed in both plant and animal cells tested in this study.

\section{Methods}

\section{Mouse cell lines and plant seeds}

Mouse 3 T3-L1 preadipocytes and RAW264.7 macrophages were purchased from American Type Culture Collection (Manassas, VA). The cells were kept under liquid nitrogen vapor in a Cryogenic Storage Vessel (Thermo Fisher Scientific, Waltham, MA). Tung trees (Aleurites fordii Hemsl.) were grown in the American Tung Oil Corporation orchard (Lumberton, Mississippi). Company officer John Corley granted permission of the tung tree fruits for our project. Tung fruits were collected weekly for a total of 11 weeks (seed stage 1-11) beginning 9 weeks after full bloom and 1 month before the initiation

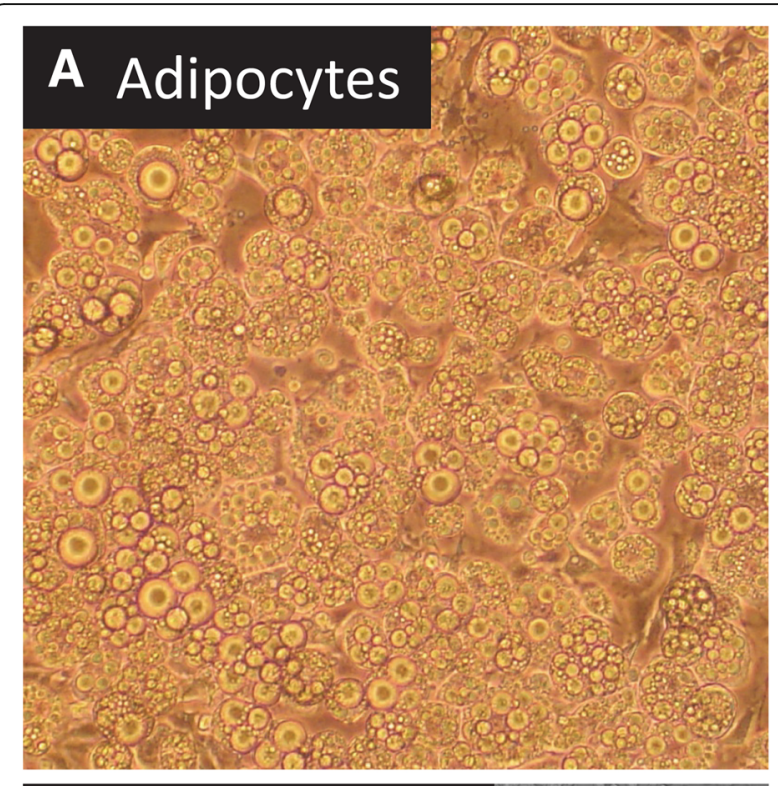

\section{B Macrophages}
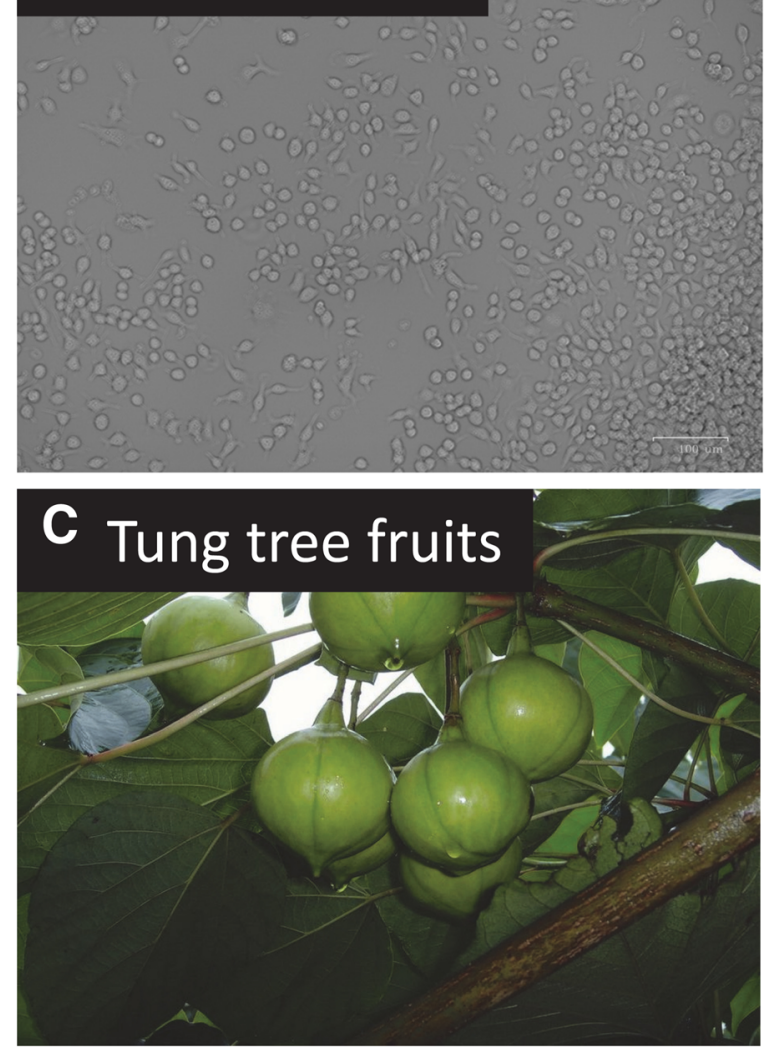

Fig. 1 Mouse cells and plant seeds used in the study. a Differentiated mouse adipocytes (magnification: 40x). Mouse 3 T3-L1 fibroblasts were differentiated in the induction medium containing insulin, dexamethasone and 1-isobutyl-3-methylxanthine. Microscopic observation indicated that approximately $90 \%$ of the cells accumulated lipid drops, an indication of differentiation from preadipocytes to adipocytes. b RAW264.7 macrophages (no magnification). c Tung tree seeds 
of storage oil synthesis as stage 1 seed [25]. Kernels from tung tree seeds from stages 5 to 11 were immediately frozen in liquid $\mathrm{N}_{2}$ and stored at $-80^{\circ} \mathrm{C}$ before use.

\section{Chemicals, reagents and equipment}

Chemicals, reagents and equipment used in the current study were mostly described previously [38, 39]. Tissue culture reagents were from Gibco BRL (Thermo Fisher). Tissue culture incubator was water jacket $\mathrm{CO}_{2}$ incubator, Forma Series II, Model 3100 Series (Thermo Fisher). Tissue culture workstation was Logic+ A2 hood (Labconco, Kansas City, MO). Tissue culture plastic ware was from CytoOne (USA Scientific, Ocala, FL). Cell counting reagent (trypsin blue dye), slides (dual chamber), counter (TC20 Automatic Cell Counter) and microscope (Zoe Florescent Cell Imager) were from Bio-Rad (Hercules, CA). RNA purification reagent (TRIzol), dryer (Integrated SpeedVac System) and quantitation (NanoPhotometer) were from Thermo Fisher, Thermo Fisher and Implen (Munchen, Germany), respectively. cDNA synthesis equipment (DNA Engine, Gradient Cycler, PTC-200) and 8-strip thin-well tubes were from MJ Research (Waltham, MA). cDNA synthesis plate (96-well plate) was from ABgene (Thermo Fisher). cDNA synthesis reagents (SuperScript II reverse transcriptase, oligo $(\mathrm{dT})_{12-18}$ primer, random primers, dNTPs, DTT, RNaseOUT) were from Life Technologies. qPCR equipment (CFX96 real-time system-C1000 Thermal Cycler), reagent $(1 \times$ iQ SYBR Green Supermix) and accessories (plates and sealing film) were from Bio-Rad. Other chemicals (LPS, gossypol, DMSO, chloroform, hexane, and ethanol) were from Sigma.

\section{Cell culture}

Mouse $3 \mathrm{~T} 3-\mathrm{L} 1$ fibroblasts were maintained in a humidified incubator at $37^{\circ} \mathrm{C}$ with $5 \% \mathrm{CO}_{2}$ in Dulbecco's modified Eagle's medium (DMEM) containing 4500 $\mathrm{mg} / \mathrm{l}(25 \mathrm{mM})$ glucose supplemented with $10 \%(\mathrm{v} / \mathrm{v})$ fetal bovine serum, $100 \mathrm{U} / \mathrm{ml}$ penicillin, $100 \mu \mathrm{g} / \mathrm{ml}$ streptomycin, and $2 \mathrm{mM} \mathrm{L-glutamine}$ (DMEM+). Adipocyte differentiation was induced as described [40]. Briefly, mouse $3 \mathrm{~T} 3-\mathrm{L} 1$ fibroblasts (about 0.2 million cells/2-ml medium/well) were grown in 6-well plates under the same conditions for $48-60 \mathrm{~h}$ and the medium was replaced with fresh DMEM+. After incubation for another $48-60 \mathrm{~h}$, the medium was replaced with differentiation medium containing DMEM,$+ 1 \mu \mathrm{g} / \mathrm{ml}$ of the recombinant human insulin, $0.25 \mu \mathrm{M}$ dexamethasone, and $250 \mu \mathrm{M}$ IBMX. Following incubation for $48-60 \mathrm{~h}$, the differentiation medium was replaced with DMEM+ containing only $1 \mu \mathrm{g} / \mathrm{ml}$ of insulin. After incubation for additional 48-60 h, the medium was replaced with DMEM+ and the cells were grown for an additional 4-6 days. Microscopic observation indicated that approximately $90 \%$ of the cells accumulated lipid drops (indication of differentiation from preadipocytes to adipocytes) (Fig. 1a). The adipocytes were then serum-starved for $4 \mathrm{~h}$ in DMEM without any supplementation or with \% DMSO and collected at various time points for RNA extraction.

Mouse RAW264.7 macrophages were maintained in polystyrene tissue culture flasks as described [41] at $37^{\circ} \mathrm{C}$ in a water jacket $\mathrm{CO}_{2}$ incubator with $5 \% \mathrm{CO}_{2}$ in DMEM containing $4.5 \mathrm{mg} / \mathrm{ml}(25 \mathrm{mM})$ glucose supplemented with $10 \%$ (v:v) fetal bovine serum, 100 units/ml penicillin, $100 \mu \mathrm{g} / \mathrm{ml}$ streptomycin, and $2 \mathrm{mML}$-glutamine. RAW macrophages were dissociated from the flask with a cell scraper, stained with equal volume of $0.4 \%$ trypsin blue dye before counting the number of live cells with a TC20 Automatic Cell Counter. RAW cells $(0.5 \mathrm{ml})$ were subcultured at approximately $1 \times 10^{5}$ cells $/ \mathrm{ml}$ density in 12-well tissue culture plates. The macrophages were subcultured for two days before being added with $0.1-1 \%$ DMSO and collected at various time points for RNA extraction. Mouse RAW macrophages were observed routinely under a Zoe Florescent Cell Imager before and under treatment (Fig. 1b).

\section{RNA extraction}

Mouse cells in culture plates were washed with $1 \mathrm{ml}$ $0.9 \% \mathrm{NaCl}$ twice and lysed directly with $1 \mathrm{ml}$ of TRIzol reagent. RNA was isolated according to the manufacturer's instructions. Tung seeds (Fig. 1c) were ground into powder under liquid nitrogen. Total RNAs were isolated by Spectrum Plant Total RNA Kit as described [32]. RNA concentrations and quantity were determined using RNA 6000 Nano Assay Kit and the Bioanalyzer 2100 according to the manufacturer's instructions with RNA 6000 Ladder as the standards [35]. RNA concentrations were also quantified with an Implen NanoPhotometer. The RNA preparations were of high quality as determined by high rRNA ratio $(28 \mathrm{~S} / 18 \mathrm{~S}=1.9)$ and the RNA integrity number $(\mathrm{RIN}=8.7)$.

\section{Quantitative real-time PCR analysis}

TaqMan and SYBR Green qPCR assays generally followed the MIQE guidelines [42]. Unique PCR primers and TaqMan probes for each DGAT isoform were designed using Primer Express software. They were synthesized by Biosearch Technologies, Inc. The forward primers, TaqMan probes (TET - BHQ1) and reverse primers, respectively, are described in Table 1.

The cDNAs were synthesized from total RNAs using SuperScript II reverse transcriptase. The cDNA synthesis mixture $(20 \mu \mathrm{l})$ contained $2.5-5 \mu \mathrm{g}$ total RNA, $2.4 \mu \mathrm{g}$ oligo $(\mathrm{dT})_{12-18}$ primer, $0.1 \mu \mathrm{g}$ random primers, $500 \mu \mathrm{M}$ dNTPs, $10 \mathrm{mM}$ DTT, 40 units RNaseOUT and 200 units SuperScript II reverse transcriptase in $1 \mathrm{X}$ first-strand synthesis 


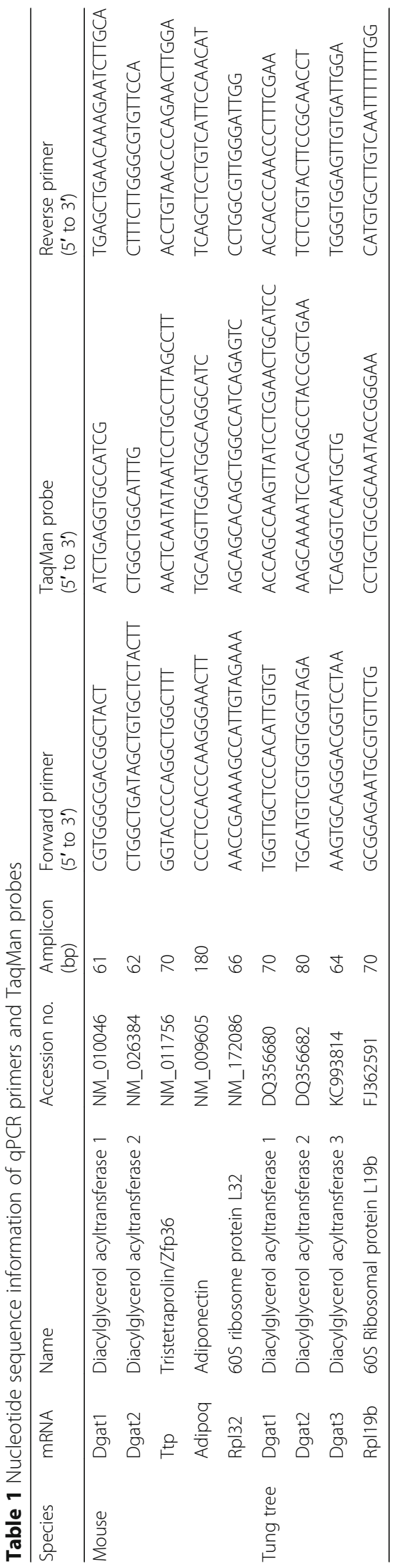


buffer. The cDNA synthesis reactions were at $42{ }^{\circ} \mathrm{C}$ for 50 min. The cDNA samples were stored in $-80^{\circ} \mathrm{C}$ freezer and diluted with water to $1 \mathrm{ng} / \mu$ l before analyses.

TaqMan qPCR mixtures contained $5 \mathrm{ng}$ of cDNAs except Table 2 using $25 \mathrm{ng}$ cDNAs, $200 \mathrm{nM}$ each of the forward primer, reverse primer and TaqMan probe, and Absolute QPCR Mix [35]. The thermal cycling conditions for TaqMan qPCR were $2 \mathrm{~min}$ at $50^{\circ} \mathrm{C}$ and $15 \mathrm{~min}$ at $95^{\circ} \mathrm{C}$, followed by 50 cycles at $95^{\circ} \mathrm{C}$ for $15 \mathrm{~s}$ and $60{ }^{\circ} \mathrm{C}$ for $60 \mathrm{~s}$. SYBR Green qPCR mixtures contained $5 \mathrm{ng}$ of cDNAs, $200 \mathrm{nM}$ each of forward primer and reverse primer and iQ SYBR Green Supermix. The thermal cycle conditions for SYBR Green qPCR were $3 \mathrm{~min}$ at $95^{\circ} \mathrm{C}$, followed by 40 cycles at $95^{\circ} \mathrm{C}$ for $10 \mathrm{~s}, 65^{\circ} \mathrm{C}$ for $30 \mathrm{~s}$ and $72{ }^{\circ} \mathrm{C}$ for $30 \mathrm{~s}$. The qPCR reactions were performed in 96-well clear plates sealed by adhesives with an ABI Prism 7700 real time PCR instrument or a CFX96 real-time system-C1000 Thermal Cycler. Both types of equipment were shown to be reliable for qPCR analyses [34].

\section{Data analysis}

The fold change in expression was determined by the $\Delta \Delta \mathrm{C}_{\mathrm{T}}$ method of relative quantification [43]. First, the mean and standard deviation of the cycle of threshold $\left(C_{T}\right)$ was obtained from independent samples. Second, the first delta $C_{T}$ value $\left(\Delta C_{T}\right)$ was obtained by subtracting the $C_{T}$ values of the internal reference control, mouse $60 \mathrm{~S}$ ribosome protein 32 (Rpl32) or tung tree 60s Rpl19b from the mean $C_{\mathrm{T}}$ values of the target mRNAs $\left(\Delta \mathrm{C}_{\mathrm{T}}=\mathrm{C}_{\mathrm{TTarget}}-\mathrm{C}_{\text {Tref }}\right)$. The selection of these two internal reference controls was based on our previous studies showing that RPL32 and RPL19b were the most stably expressed genes in the mouse cells and tung tree tissues, respectively $[33,44]$. Third, the second delta $C_{T}$ value $\left(\Delta \Delta \mathrm{C}_{\mathrm{T}}\right)$ was obtained by subtracting the $\Delta C_{\mathrm{T}}$ of the calibrator, time-point $0 \mathrm{~min}$, TTP control, adipocytes, or DGAT1 in tune tree seed from the $\Delta \mathrm{C}_{\mathrm{T}}$ of the target mRNAs $\left(\Delta \Delta \mathrm{C}_{\mathrm{T}}=\Delta \mathrm{C}_{\mathrm{T} \text { Target }}-\Delta \mathrm{C}_{\mathrm{Tcal}}\right)$. Fourth, the fold change in expression was obtained using the eq.

Table 2 Relative abundance of Rpl32 and Adipoq mRNAs in mouse adipocytes

\begin{tabular}{lllll}
\hline $\begin{array}{l}\text { Time } \\
(\mathrm{min})\end{array}$ & mRNA & $\begin{array}{l}\mathrm{C}_{\mathrm{T}} \pm \mathrm{SD} \\
(n=2-4)\end{array}$ & $\begin{array}{l}\Delta \mathrm{C}_{\mathrm{T}} \\
\left(\mathrm{C}_{\text {TAdipoq }}-\mathrm{C}_{\text {TRpl32 }}\right)\end{array}$ & $\begin{array}{l}\text { Fold } \\
\left(2^{-\Delta C \mathrm{C}}\right)\end{array}$ \\
\hline 0 & Rpl32 & $18.08 \pm 0.13$ & 0.00 & 1.00 \\
& Adipoq & $19.10 \pm 0.14$ & 1.03 & 0.49 \\
30 & Rpl32 & $17.91 \pm 0.16$ & 0.00 & 1.00 \\
& Adipoq & $19.34 \pm 0.28$ & 1.43 & 0.37 \\
60 & Rpl32 & $19.40 \pm 0.10$ & 0.00 & 1.00 \\
& Adipoq & $20.27 \pm 0.00$ & 0.87 & 0.55 \\
90 & Rpl32 & $18.20 \pm 0.09$ & 0.00 & 1.00 \\
& Adipoq & $19.12 \pm 0.17$ & 0.92 & 0.53 \\
\hline
\end{tabular}

$\left(2^{-\Delta \Delta C T}\right)$. Finally, the ratio of Dgat2's fold change/Dgat1's fold change over 2 , i.e., $\left[\left(2^{-\Delta \Delta C \mathrm{~T}}\right)\right.$ of Dgat $2 /\left[\left(2^{-\Delta \Delta C \mathrm{~T}}\right)\right.$ of Dgat $1>2$ ], was used as the threshold for significant differences in gene expression [45-48].

\section{Results \\ Cycle of threshold of RPL32, TTP and DGAT mRNAs in mouse adipocytes}

Mouse 3 T3-L1 fibroblasts were differentiated into adipocytes by insulin, dexamethasone, and 1-isobutyl-3-methylxanthine (IBMX). Microscopic observation showed that almost all adipocytes accumulated lipid droplets (indication of differentiation from preadipocytes to adipocytes) (Fig. 1a). The expression level of a gene coding for adipocyte-specific cytokine, adiponectin (ADIPOQ) was extremely abundant and close to half of the house-keeping RPL32 mRNA levels in the adipocytes (Table 2). Adiponectin mRNA levels were 49, 37, 55 and $53 \%$ of RPL32 mRNA levels in adipocytes collected at 0, 30, 60 and 90-min, respectively (Table 2), in agreement with previous results showing that ADIPOQ mRNA is one of the most abundant adipokines [49]. ADIPOQ expression data support the microscopic observation that the adipocytes were properly differentiated under the experimental conditions.

\section{Time-course of RPL32, TTP and DGAT mRNAs in mouse adipocytes}

The adipocytes were serum-starved in DMEM without any supplementation for $4 \mathrm{~h}$ before collecting cells at 0 , 30,60 , and $90 \mathrm{~min}$. Total RNAs were extracted from the cells, converted into cDNAs, and analyzed by TaqMan qPCR method using primers and probes as shown in Table 1 . The $C_{T}$ values for each of the mRNA tested including the reference gene RPL32, positive control gene TTP, and DGAT1 and DGAT2 genes were very similar among the cells collected at various time-points following starvation (Fig. 2). These qPCR data were used to calculate mRNA levels in mouse cells using the formula $\left(2^{-\Delta \Delta \mathbf{C T}}\right)$. RPL32 mRNA levels were similar among the four time points with only slightly increased in the 90 min sample after 4-h serum-starvation. The differences of gene expression among the cells collected at various time-points after serum starvation were less than 2 -fold difference, i.e., the ratio $\left(2^{-\Delta \Delta \mathbf{C T}}\right)$ is $<2$. Therefore, these genes were expressed relatively stable in mouse adipocytes under the experimental conditions.a

\section{Relative abundance of TTP and DGAT mRNAs in mouse adipocytes}

Table 3 shows the relative expression abundance of TTP and DGAT genes in mouse adipocytes. At the start of collecting cells (0 min after 4-h serum starvation), DGAT1 mRNA levels were 1 -fold of TTP mRNA. Importantly, 


\section{mRNA Stability in Mouse Adipocytes}

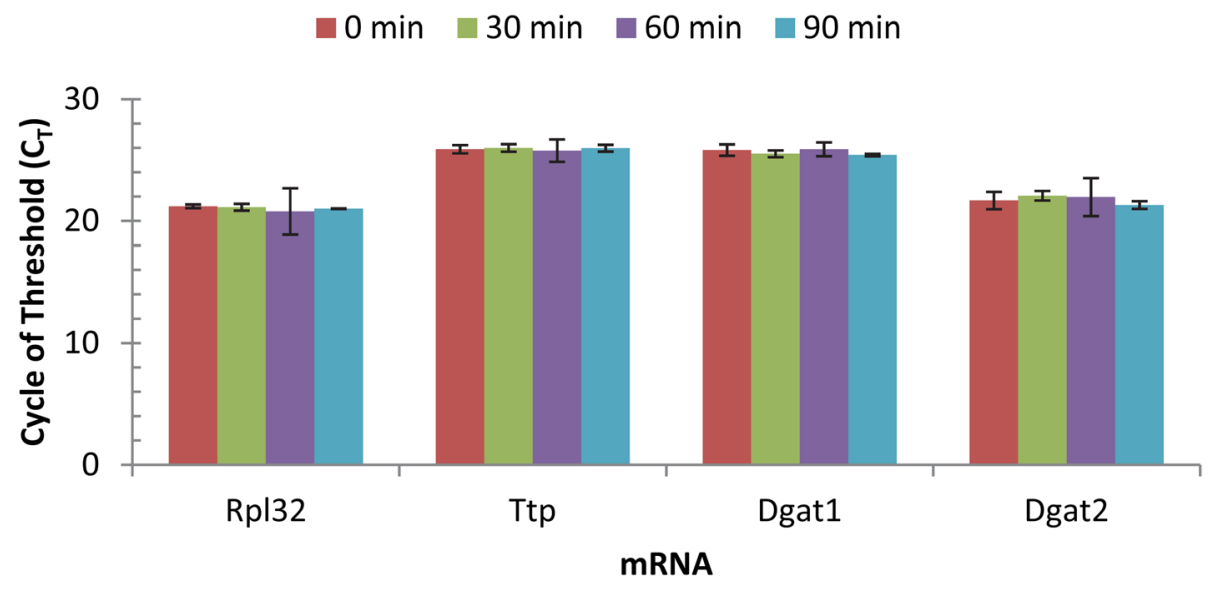

Fig. 2 TTP and DGAT mRNAs were stable in mouse adipocytes. The differentiated 3T3-L1 adipocytes were serum-starved for $4 \mathrm{~h}$ in DMEM without any supplementation and collected at various time points (0, 30, 60, and 90 min after 4-h starvation) for RNA extraction and cDNA synthesis. TaqMan qPCR assay evaluated Rpl32, Ttp, Dgat1, and Dgat2 gene expression. The data represent the mean and standard deviation of four assays

DGAT2 mRNA levels were 19-fold of TTP and 18-fold of DGAT1 (Table 3). Similarly, DGAT1 mRNA levels were 1-fold of TTP mRNA, but DGAT2 mRNA levels were 15-fold of TTP and 11-fold of DGAT1 in adipocytes collected at $30 \mathrm{~min}$ (Table 3). In adipocytes collected at 60 min, DGAT1 mRNA levels were 1-fold of TTP mRNA, but DGAT2 mRNA levels were 14-fold of TTP and 15-fold of DGAT1 (Table 3). At the last time point (90 min), DGAT2 mRNA levels were 26-fold of TTP and still 17-fold of DGAT1 (Table 3). These data demonstrated that DGAT2 mRNA levels were at least 10-fold higher than both DGAT1 and TTP and that DGAT1 and TTP mRNA levels were similar in the adipocytes regardless of

Table 3 Relative abundance of TTP and DGAT mRNAs in mouse adipocytes

\begin{tabular}{lllll}
\hline $\begin{array}{l}\text { Time } \\
(\mathrm{min})\end{array}$ & mRNA & $\begin{array}{l}\mathrm{C}_{\mathrm{T}} \pm \mathrm{SD} \\
(n=4)\end{array}$ & $\begin{array}{l}\text { Fold } \\
\left(2^{-\Delta \Delta C \mathrm{~T}}\right)\end{array}$ & $\begin{array}{l}\text { Fold } \\
\text { (Dgat2/Dgat1) }\end{array}$ \\
\hline 0 & Ttp & $25.89 \pm 0.34$ & 1.00 & \\
& Dgat1 & $25.82 \pm 0.47$ & 1.05 & 1.00 \\
& Dgat2 & $21.68 \pm 0.71$ & 18.51 & 17.63 \\
30 & Ttp & $26.00 \pm 0.31$ & 1.00 & \\
& Dgat1 & $25.52 \pm 0.28$ & 1.39 & 1.00 \\
& Dgat2 & $22.07 \pm 0.39$ & 15.24 & 10.96 \\
60 & Ttp & $25.78 \pm 0.92$ & 1.00 & \\
& Dgat1 & $25.89 \pm 0.57$ & 0.93 & 1.00 \\
& Dgat2 & $21.96 \pm 1.56$ & 14.12 & 15.18 \\
90 & Ttp & $25.98 \pm 0.28$ & 1.00 & \\
& Dgat1 & $25.42 \pm 0.10$ & 1.47 & 1.00 \\
& Dgat2 & $21.31 \pm 0.32$ & 25.46 & 17.32 \\
\hline
\end{tabular}

culture medium conditions might being changed over time during the course of cell culture.

\section{Relative abundance of TTP and DGAT mRNAs in DMSO- treated mouse adipocytes}

Since dimethylsulfoxide (DMSO) was used frequently as a solvent for many chemicals in cell cultures and was shown to increase lipolysis under high concentration [50], we analyzed the relative levels of TTP and DGAT gene expression by TaqMan $\mathrm{qPCR}$ in the same way

Table 4 Relative abundance of TTP and DGAT mRNAs in DMSO-treated mouse adipocytes

\begin{tabular}{lllll}
\hline $\begin{array}{l}\text { Time } \\
(\mathrm{min})\end{array}$ & mRNA & $\begin{array}{l}\mathrm{C}_{\mathrm{T}} \pm \mathrm{SD} \\
(n=4)\end{array}$ & $\begin{array}{l}\text { Fold } \\
\left(2^{-\Delta \Delta C \mathrm{~T}}\right)\end{array}$ & $\begin{array}{l}\text { Fold } \\
\text { (Dgat2/Dgat1) }\end{array}$ \\
\hline 0 & Ttp & $26.43 \pm 0.09$ & 1.00 & \\
& Dgat1 & $25.53 \pm 0.09$ & 1.87 & 1.00 \\
& Dgat2 & $21.24 \pm 0.11$ & 36.50 & 19.52 \\
30 & Ttp & $25.92 \pm 0.12$ & 1.00 & \\
& Dgat1 & $25.71 \pm 0.19$ & 1.16 & 1.00 \\
& Dgat2 & $21.16 \pm 0.36$ & 27.10 & 23.36 \\
60 & Ttp & $26.66 \pm 0.38$ & 1.00 & \\
& Dgat1 & $25.60 \pm 0.05$ & 2.08 & 1.00 \\
& Dgat2 & $20.86 \pm 0.32$ & 55.72 & 26.79 \\
90 & Ttp & $26.92 \pm 0.37$ & 1.00 & \\
& Dgat1 & $25.80 \pm 0.20$ & 2.17 & 1.00 \\
& Dgat2 & $21.32 \pm 0.30$ & 48.50 & 22.35 \\
120 & Ttp & $26.61 \pm 0.01$ & 1.00 & \\
& Dgat1 & $25.89 \pm 0.10$ & 1.65 & 1.00 \\
& Dgat2 & $22.63 \pm 0.10$ & 15.78 & 9.56 \\
\hline
\end{tabular}


using adipocytes treated with $0.1 \%$ DMSO (Table 4). DGAT2 mRNA levels were 20-, 23-, 27-, 22- and 10-fold of DGAT1, and were 37-, 27-, 56-, 49- and 16-fold of TTP in adipocytes collected at $0,30,60,90$, and $120 \mathrm{~min}$, respectively (Table 4). DGAT1 mRNA levels were approximately 2 -fold or less of TTP in the DMSO-treated adipocytes collected at various times (Table 4). Addition of $0.1 \%$ DMSO in the culture medium increased the ratio of DGAT2 over DGAT1 mRNAs in the mouse adipocytes, mainly due to increased expression of DGAT2 in the cells (Table 4 vs. Table 3). These data confirmed the conclusion from the above experiments without DMSO in the culture medium that DGAT2 mRNA levels were at least 10-fold higher than both DGAT1 and TTP in mouse 3 T3-L1 adipocytes.

Relative abundance of TTP and DGAT mRNAs in DMSOtreated mouse macrophages

To confirm if DGAT2 mRNA is a major form of DGAT mRNA in different types of cells, the relative expression levels of these same genes were analyzed by TaqMan qPCR in $0.1 \%$ DMSO-treated mouse RAW264.7 macrophages, a cell type with minimal lipid biosynthesis. DGAT1 mRNA levels were only $1 \%$ of TTP in macrophages collected at each of the five time points $(0,30$, 60, 90, 120, $240 \mathrm{~min}$ ) (Table 5). DGAT2 mRNA levels were $16,19,16,24$, and $10 \%$ of TTP mRNA levels in macrophages collected at $0,30,60,90,120$, and $240 \mathrm{~min}$, respectively (Table 5). DGAT2 mRNA levels were 16-, 19-, 16-, 24- and 10-fold of DGAT1 mRNA levels in macrophages collected at $0,30,60,90,120$, and $240 \mathrm{~min}$,

Table 5 Relative abundance of TTP and DGAT mRNAs in DMSO-treated mouse macrophages

\begin{tabular}{lllll}
\hline $\begin{array}{l}\text { Time } \\
(\mathrm{min})\end{array}$ & mRNA & $\begin{array}{l}\mathrm{C}_{\mathrm{T}} \pm \mathrm{SD} \\
(n=4)\end{array}$ & $\begin{array}{l}\text { Fold } \\
\left(2^{-\Delta \Lambda \mathrm{CT}}\right)\end{array}$ & $\begin{array}{l}\text { Fold } \\
\text { (Dgat2/Dgat1) }\end{array}$ \\
\hline 0 & Ttp & $24.94 \pm 0.25$ & 1.00 & \\
& Dgat1 & $31.63 \pm 0.30$ & 0.01 & 1.00 \\
& Dgat2 & $27.60 \pm 1.01$ & 0.16 & 16.00 \\
30 & Ttp & $24.90 \pm 0.17$ & 1.00 & \\
& Dgat1 & $31.13 \pm 0.23$ & 0.01 & 1.00 \\
& Dgat2 & 27.27 & 0.19 & 19.00 \\
60 & Ttp & $24.34 \pm 0.10$ & 1.00 & \\
& Dgat1 & $31.79 \pm 0.14$ & 0.01 & 1.00 \\
& Dgat2 & $27.01 \pm 0.60$ & 0.16 & 16.00 \\
120 & Ttp & $24.93 \pm 0.25$ & 1.00 & \\
& Dgat1 & $31.89 \pm 0.27$ & 0.01 & 1.00 \\
& Dgat2 & $27.01 \pm 2.06$ & 0.24 & 24.00 \\
240 & Ttp & $25.09 \pm 0.14$ & 1.00 & \\
& Dgat1 & $31.84 \pm 0.20$ & 0.01 & 1.00 \\
& Dgat2 & $28.48 \pm 0.72$ & 0.10 & 10.00 \\
\hline
\end{tabular}

respectively (Table 5). These data further confirmed the conclusion from the above experiments from adipocytes that DGAT2 mRNA was the major DGAT mRNA in the cultured mouse cells, although DGAT mRNA levels were much lower than TTP in macrophages.

\section{Relative abundance of TTP and DGAT mRNAs in DMSO- treated mouse macrophages by SYBR green qPCR assay} To prove that DGAT2 mRNA was the major DGAT gene expressed in the mouse cells from TaqMan qPCR assays, SYBR Green qPCR was used to confirm the expression levels of these four genes in DMSO-treated mouse macrophages. As shown in Table 6, DGAT1 mRNA levels were $0.4,4$ and $1 \%$ of TTP in RAW264.7 macrophages collected in 2,8 , and $24 \mathrm{~h}$, respectively. Similarly, DGAT2 mRNA levels were 2, 25 and $12 \%$ of TTP in RAW264.7 macrophages collected in 2, 8, and $24 \mathrm{~h}$, respectively. Again, DGAT2 mRNA levels were 5-, 6- and 12-fold of DGAT1 (Table 6). These data further confirmed the conclusion from previous experiments using TaqMan qPCR assay that DGAT2 mRNA was the major DGAT mRNA in the mouse cells, although the fold of difference between DGAT2 and DGAT1 mRNAs by SYBR Green qPCR assay was less than that from TaqMan qPCR assay. These results also showed that DGAT2 mRNA was the major form of DGAT transcript in mouse macrophages under higher DMSO concentration for longer treatment time, a similar trend from TaqMan qPCR assays using macrophages cultured under lower DMSO concentration for shorter treatment.

\section{Relative abundance of TTP and DGAT mRNAs between mouse adipocytes and macrophages}

TTP and DGAT mRNA levels were compared between the two types of cells used in the analysis. Table 7 shows that TTP mRNA levels in macrophages were 2-fold of those in adipocytes in 0-min sample. The ratio was similar in 30-min sample (2-fold) but increased to 4-fold in

Table 6 Relative abundance of TTP and DGAT mRNAs in DMSO-treated mouse macrophages by SYBR Green qPCR

\begin{tabular}{lllll}
\hline $\begin{array}{l}\text { Time } \\
(\mathrm{h})\end{array}$ & mRNA & $\begin{array}{l}\mathrm{C}_{\mathrm{T}} \pm \mathrm{SD} \\
(n=4-8)\end{array}$ & $\begin{array}{l}\text { Fold } \\
\left(2^{-\Delta \Delta \mathrm{CT}}\right)\end{array}$ & $\begin{array}{l}\text { Fold } \\
\text { (Dgat2/Dgat1) }\end{array}$ \\
\hline 2 & Ttp & $24.40 \pm 0.90$ & 1.00 & \\
& Dgat1 & $30.51 \pm 0.68$ & 0.004 & 1.00 \\
& Dgat2 & $28.39 \pm 0.93$ & 0.02 & 5.00 \\
8 & Ttp & $26.88 \pm 0.93$ & 1.00 & \\
& Dgat1 & $31.69 \pm 1.97$ & 0.04 & 1.00 \\
& Dgat2 & $28.90 \pm 1.43$ & 0.25 & 6.17 \\
24 & Ttp & $24.76 \pm 1.44$ & 1.00 & \\
& Dgat1 & $31.10 \pm 1.53$ & 0.01 & 1.00 \\
& Dgat2 & $27.86 \pm 0.65$ & 0.12 & 12.00 \\
\hline
\end{tabular}


Table 7 Relative abundance of TTP and DGAT mRNAs between mouse cells

\begin{tabular}{|c|c|c|c|c|}
\hline$\overline{\mathrm{mRNA}}$ & $\begin{array}{l}\text { Time } \\
\text { (min) }\end{array}$ & Cell & $\begin{array}{l}\mathrm{C}_{\mathrm{T}} \pm \mathrm{SD} \\
(n=4)\end{array}$ & $\begin{array}{l}\text { Fold } \\
\left(2^{-\Delta \Delta C T}\right)\end{array}$ \\
\hline \multirow[t]{8}{*}{ Ttp } & \multirow[t]{2}{*}{0} & Adipocytes & $26.43 \pm 0.09$ & 1.00 \\
\hline & & Macrophages & $24.94 \pm 0.25$ & 1.92 \\
\hline & \multirow[t]{2}{*}{30} & Adipocytes & $25.92 \pm 0.12$ & 1.00 \\
\hline & & Macrophages & $24.90 \pm 0.17$ & 1.48 \\
\hline & \multirow[t]{2}{*}{60} & Adipocytes & $26.66 \pm 0.38$ & 1.00 \\
\hline & & Macrophages & $24.34 \pm 0.10$ & 3.51 \\
\hline & \multirow[t]{2}{*}{120} & Adipocytes & $26.61 \pm 0.01$ & 1.00 \\
\hline & & Macrophages & $24.93 \pm 0.25$ & 1.34 \\
\hline \multirow[t]{8}{*}{ Dgat1 } & \multirow[t]{2}{*}{0} & Adipocytes & $25.53 \pm 0.09$ & 1.00 \\
\hline & & Macrophages & $31.63 \pm 0.30$ & 0.01 \\
\hline & \multirow[t]{2}{*}{30} & Adipocytes & $25.71 \pm 0.19$ & 1.00 \\
\hline & & Macrophages & $31.13 \pm 0.23$ & 0.02 \\
\hline & \multirow[t]{2}{*}{60} & Adipocytes & $25.60 \pm 0.05$ & 1.00 \\
\hline & & Macrophages & $31.79 \pm 0.14$ & 0.01 \\
\hline & \multirow[t]{2}{*}{120} & Adipocytes & $25.89 \pm 0.10$ & 1.00 \\
\hline & & Macrophages & $31.89 \pm 0.27$ & 0.01 \\
\hline \multirow[t]{8}{*}{ Dgat2 } & \multirow[t]{2}{*}{0} & Adipocytes & $21.24 \pm 0.11$ & 1.00 \\
\hline & & Macrophages & $27.60 \pm 1.01$ & 0.01 \\
\hline & \multirow[t]{2}{*}{30} & Adipocytes & $21.16 \pm 0.36$ & 1.00 \\
\hline & & Macrophages & $27.27 \pm 0.00$ & 0.02 \\
\hline & \multirow[t]{2}{*}{60} & Adipocytes & $20.86 \pm 0.32$ & 1.00 \\
\hline & & Macrophages & $27.01 \pm 0.60$ & 0.01 \\
\hline & \multirow[t]{2}{*}{120} & Adipocytes & $22.63 \pm 0.10$ & 1.00 \\
\hline & & Macrophages & $27.01 \pm 2.06$ & 0.02 \\
\hline
\end{tabular}

60-min sample and returned to 1 -fold in 120-min sample (Table 7). DGAT1 and DGAT2 mRNA levels in macrophages were only $1-2 \%$ of those in adipocytes in 0,30 , 60 , and $120 \mathrm{~min}$ samples (Table 7).

\section{Relative abundance of DGAT mRNAs in developing tung seeds}

To evaluate whether DGAT2 mRNA was the major form of DGAT expressed in other eukaryotes, relative expression of three DGAT genes in the developing seeds from three separate field-grown tung trees was measured by TaqMan qPCR using well-characterized RPL19b as an internal reference control [33]. In tung tree seeds with active oil accumulation (stage 5-11 seeds), DGAT2 mRNA levels were approximately 8-, 5-, 6-, 6-, 20-, 17- and 13-fold of DGAT1 in the seeds collected at $5,6,7,8,9,10$, and 11 stages, respectively (Table 8). DGAT3 mRNA levels were 0.4-, 0.3-, 0.2-, 0.2 -, 0.1 -, 0.2 - and 0.2 -fold of DGAT2 in the seeds collected at $5,6,7,8,9,10$, and 11 stages, respectively
Table 8 Relative abundance of DGAT mRNAs in tung tree seeds

\begin{tabular}{|c|c|c|c|c|}
\hline Seed stage & mRNA & $\begin{array}{l}C_{T} \pm S D \\
(n=3)\end{array}$ & $\begin{array}{l}\text { Fold } \\
\left(2^{-\Delta \Delta C T}\right)\end{array}$ & $\begin{array}{l}\text { Fold } \\
\text { (Dgat3/Dgat2) }\end{array}$ \\
\hline \multirow[t]{3}{*}{5} & Dgat1 & $26.62 \pm 0.47$ & 1.00 & \\
\hline & Dgat2 & $23.58 \pm 0.98$ & 8.21 & 1.00 \\
\hline & Dgat3 & $25.10 \pm 1.42$ & 2.87 & 0.35 \\
\hline \multirow[t]{3}{*}{6} & Dgat1 & $26.28 \pm 0.80$ & 1.00 & \\
\hline & Dgat2 & $23.58 \pm 0.98$ & 5.15 & 1.00 \\
\hline & Dgat3 & $25.57 \pm 0.60$ & 1.64 & 0.32 \\
\hline \multirow[t]{3}{*}{7} & Dgat1 & $26.10 \pm 0.69$ & 1.00 & \\
\hline & Dgat2 & $23.63 \pm 1.03$ & 5.56 & 1.00 \\
\hline & Dgat3 & $26.17 \pm 1.29$ & 0.95 & 0.17 \\
\hline \multirow[t]{3}{*}{8} & Dgat1 & $26.21 \pm 0.46$ & 1.00 & \\
\hline & Dgat2 & $23.69 \pm 1.18$ & 5.75 & 1.00 \\
\hline & Dgat3 & $26.19 \pm 0.54$ & 1.01 & 0.18 \\
\hline \multirow[t]{3}{*}{9} & Dgat1 & $26.94 \pm 1.00$ & 1.00 & \\
\hline & Dgat2 & $22.62 \pm 1.83$ & 20.04 & 1.00 \\
\hline & Dgat3 & $25.83 \pm 0.75$ & 2.16 & 0.11 \\
\hline \multirow[t]{3}{*}{10} & Dgat1 & $27.07 \pm 1.88$ & 1.00 & \\
\hline & Dgat2 & $22.95 \pm 0.60$ & 17.33 & 1.00 \\
\hline & Dgat3 & $25.44 \pm 0.52$ & 3.11 & 0.18 \\
\hline \multirow[t]{3}{*}{11} & Dgat1 & $26.79 \pm 0.36$ & 1.00 & \\
\hline & Dgat2 & $23.12 \pm 0.76$ & 12.74 & 1.00 \\
\hline & Dgat3 & $25.60 \pm 0.40$ & 2.28 & 0.18 \\
\hline
\end{tabular}

(Table 8). These data support the concept that DGAT2 mRNA is the major form of DGAT expressed in both oil-filling tung tree seeds and the two cultured mouse cells.

\section{Discussion}

Diacylglycerol acyltransferases (DGATs) catalyze the final and rate-limiting step of TAG biosynthesis. Animals contain two isoforms but plants and yeast contain three isoforms of DGATs [21, 26, 27, 51, 52]. Genetic studies have demonstrated that DGAT isoforms have non-redundant functions in TAG biosynthesis in mice [5] and tung tree $[21,53]$. DGAT2 has been shown to be the major form of DGAT in tung tree seeds [21, 25]. However, it was not clear which form of DGAT was the major isoform expressed in cultured mammalian cells.

The major finding of this report is that DGAT2 mRNA is the major form of DGAT expressed in mouse adipocytes and macrophages, similar to the oil-rich seeds of tung tree. Several lines of evidence support this conclusion. First, DGAT2 mRNA levels were much higher than DGAT1 mRNA levels in mouse 3 T3-L1 adipocytes. Second, DGAT2 mRNA levels were also much higher than DGAT1 mRNA levels in DMSO-treated adipocytes. Third, DGAT2 mRNA was the major one in DMSO-treated mouse 
RAW264.7 macrophages. Fourth, the above results using TaqMan qPCR assay were confirmed by SYBR Green qPCR assay, although SYBR Green qPCR assay was not as sensitive as TaqMan qPCR assay as reported [32, 34]. Finally, DGAT family gene expression profiles in the cultured mouse cells were similar to those in the developing seeds of tung tree where DGAT2 mRNA levels in developing seeds were up to 20-fold and 9-fold higher than DGAT1 and DGAT3, respectively. The relative abundance of DGAT mRNAs in tung tree seeds is similar between this report and a previous report [25]. In addition, DGAT2 but not DGAT1 mRNA levels were increased by DMSO, consistent with the findings that DGAT2 gene expression is up-regulated by cottonseed extracts and gossypol in mouse macrophages [39]. Finally, our experimental results reported here are in agreement with data mining results using the UCSC Genome Browser, which showed that DGAT2 expression is higher than DGAT1 expression in human adipose tissues. DGAT1 and DGAT2 mRNA levels are 40.8 and 64.9 RPKM in subcutaneous adipose, whereas they are 33.9 and 76.5 RPKM in visceral adipose collected from 8555 tissue samples of 570 adult post-mortem individuals, respectively $[54,55]$.

It was unclear if the relative abundance of DGAT1 and DGAT2 mRNAs reflects their relative abundance at the protein levels. It has been difficult to detect DGAT proteins in mammalian and plant cells mainly due to lack of good antibodies and recombinant proteins [20, 56-58]. In addition, it could be hard to compare the relative expression levels of DGAT1 vs. DGAT2 proteins directly since there is no guarantee that both antibodies will have the same titer and react to the corresponding protein linearly. Finally, it is a long way to translate mRNA abundance to functionality because so many factors may affect the final activity of the protein, such as mRNA translation at the protein level, translocation of the protein to correct compartment of the cell, protein folding, turnover and post-translational modifications. Nevertheless, these areas are very important and certainly need to be investigated thoroughly in the future.

Furthermore, the relative expression levels of DGAT genes may be different among the cell types or cellular differentiation stages. For example, DGAT1 mRNA levels are increased during fasting and return to normal levels upon refeeding in white adipocyte tissue and liver but not in brown adipocyte tissue; whereas DGAT2 mRNA levels are decreased after fasting and increased after refeeding in white adipocyte tissue but unchanged in brown adipocyte tissue or liver [59]. It was also shown that 3 T3-L1 adipocytes display phenotypic characteristics of mainly white adipocytes but also brown and beige adipocytes [60]. In this study, we only evaluated DGAT mRNA levels in differentiated adipocytes after 4-h serum starvation. It would be interesting to investigate the expression patterns of DGAT mRNAs in cultured adipocytes after refeeding in the future.

TTP gene expression was much higher in macrophages than adipocytes, whereas DGAT gene expression was much higher in lipid-synthesizing adipocytes than macrophages. TTP protein regulates gene expression at the post-transcriptional level by binding to AU-rich elements of some mRNAs and destabilizing them. TNFa and GM-CSF mRNAs are stabilized in TTP deficient mice [61, 62]. Overaccumulation of these proinflammatory cytokines in TTP knockout mice results in a severe inflammatory syndrome including arthritis, autoimmunity, and myeloid hyperplasia [63, 64]. Up-regulation of TTP reduces inflammatory responses in macrophages [65].

\section{Conclusions}

The results provide definitive evidence that DGAT2 gene expression is the major form at the mRNA level in both plant and animal cells tested in this study including tung tree seeds and mouse adipocytes and macrophages. Our conclusion was supported by results from three different cell types (mouse adipocytes, mouse macrophages, tung tree seeds), from different time-course ranging from 30 min to $24 \mathrm{~h}$ in animal cells and 1-11 weeks in developing seeds, and from both TaqMan and SYBR Green qPCR assays. This finding should be useful for targeted approach to regulating lipid/oil accumulation in plants and animals.

\section{Abbreviations \\ ADIPOQ: Adiponectin; DGAT: Diacylglycerol acyltransferases; \\ DMEM: Dulbecco's modified Eagle's medium; DMSO: Dimethylsulfoxide; qPCR: Quantitative real-time PCR; RPL19b: 60 S ribosomal protein 19b; RPL32: 60 S ribosomal protein 32; TAG: Triacylglycerol; TTP: Tristetraprolin; ZFP36: Zinc finger protein 36}

\section{Acknowledgements \\ The author thanks Dr. Kandan Sethumadhavan (USDA-ARS) for technical} assistance and Dr. Matthew K. Gilbert for critical reading the manuscript.

\section{Funding}

This work was supported by the USDA-ARS Quality and Utilization of Agricultural Products National Program 306 through Research Project 6054-41000-103-00-D. USDA is an equal opportunity provider and employer.

\section{Availability of data and materials}

The datasets used and/or analysed during the current study are available from the corresponding author on reasonable request.

\section{Author's contributions}

$\mathrm{HC}$ is the sole author thus responsible for every aspect of the paper. The author read and approved the final manuscript.

Ethics approval and consent to participate

Not applicable.

Consent for publication

Not applicable.

Competing interests

The author declares that there is no competing interest. 


\section{Publisher's Note}

Springer Nature remains neutral with regard to jurisdictional claims in published maps and institutional affiliations.

Received: 12 October 2018 Accepted: 6 December 2018 Published online: 14 December 2018

\section{References}

1. Farese RV Jr, Walther TC. Lipid droplets finally get a little R-E-S-P-E-C-T. Cell. 2009;139:855-60.

2. Liu Q, Siloto RM, Lehner R, Stone SJ, Weselake RJ. Acyl-CoA:diacylglycero acyltransferase: molecular biology, biochemistry and biotechnology. Prog Lipid Res. 2012:51:350-77.

3. Zou J, Wei Y, Jako C, Kumar A, Selvaraj G, Taylor DC. The Arabidopsis thaliana TAG1 mutant has a mutation in a diacylglycerol acyltransferase gene. Plant J. 1999;19:645-53.

4. Smith SJ, Cases S, Jensen DR, Chen HC, Sande E, Tow B, Sanan DA, Raber J, Eckel RH, Farese RV Jr. Obesity resistance and multiple mechanisms of triglyceride synthesis in mice lacking Dgat. Nat Genet. 2000;25:87-90.

5. Stone SJ, Myers HM, Watkins SM, Brown BE, Feingold KR, Elias PM, Farese RV, Jr.: Lipopenia and skin barrier abnormalities in DGAT2-deficient mice. J Biol Chem 2004:279:11767-11776.

6. Chen HC, Rao M, Sajan MP, Standaert M, Kanoh Y, Miura A, Farese RV Jr, Farese RV. Role of adipocyte-derived factors in enhancing insulin signaling in skeletal muscle and white adipose tissue of mice lacking acyl CoA: diacylglycerol acyltransferase 1. Diabetes. 2004:53:1445-51.

7. Haas JT, Winter HS, Lim E, Kirby A, Blumenstiel B, DeFelice M, Gabriel S, Jalas C, Branski D, Grueter CA, Toporovski MS, Walther TC, Daly MJ, Farese RV, Jr.: DGAT1 mutation is linked to a congenital diarrheal disorder. J Clin Invest 2012;122:4680-4684

8. Andrianov V, Borisjuk N, Pogrebnyak N, Brinker A, Dixon J, Spitsin S, Flynn J, Matyszczuk P, Andryszak K, Laurelli M, Golovkin M, Koprowski H. Tobacco as a production platform for biofuel: overexpression of Arabidopsis DGAT and LEC2 genes increases accumulation and shifts the composition of lipids in green biomass. Plant Biotechnol J. 2010;8:277-87.

9. Burgal J, Shockey J, Lu C, Dyer J, Larson T, Graham I, Browse J. Metabolic engineering of hydroxy fatty acid production in plants: RcDGAT2 drives dramatic increases in ricinoleate levels in seed oil. Plant Biotechnol J. 2008;6: 819-31.

10. Durrett TP, McClosky DD, Tumaney AW, Elzinga DA, Ohlrogge J, Pollard M. A distinct DGAT with sn-3 acetyltransferase activity that synthesizes unusual, reduced-viscosity oils in Euonymus and transgenic seeds. Proc Natl Acad Sci U S A. 2010;107:9464-9.

11. Jako C, Kumar A, Wei Y, Zou J, Barton DL, Giblin EM, Covello PS, Taylor DC. Seed-specific over-expression of an Arabidopsis CDNA encoding a diacylglycerol acyltransferase enhances seed oil content and seed weight. Plant Physiol. 2001;126:861-74.

12. Lardizabal K, Effertz R, Levering C, Mai J, Pedroso MC, Jury T, Aasen E, Gruys K, Bennett K. Expression of Umbelopsis ramanniana DGAT2A in seed increases oil in soybean. Plant Physiol. 2008;148:89-96.

13. Xu J, Francis T, Mietkiewska E, Giblin EM, Barton DL, Zhang Y, Zhang M, Taylor DC. Cloning and characterization of an acyl-CoA-dependent diacylglycerol acyltransferase 1 (DGAT1) gene from Tropaeolum majus, and a study of the functional motifs of the DGAT protein using site-directed mutagenesis to modify enzyme activity and oil content. Plant Biotechnol J. 2008;6:799-818.

14. Bouvier-Nave P, Benveniste P, Oelkers P, Sturley SL, Schaller H. Expression in yeast and tobacco of plant CDNAs encoding acyl CoA:diacylglycerol acyltransferase. Eur J Biochem. 2000;267:85-96.

15. Liu L, Zhang Y, Chen N, Shi X, Tsang B, Yu YH. Upregulation of myocellular DGAT1 augments triglyceride synthesis in skeletal muscle and protects against fat-induced insulin resistance. J Clin Invest. 2007;117:1679-89.

16. Roorda BD, Hesselink MK, Schaart G, Moonen-Kornips E, Martinez-Martinez P, Losen M, De Baets MH, Mensink RP, Schrauwen P. DGAT1 overexpression in muscle by in vivo DNA electroporation increases intramyocellular lipid content. J Lipid Res. 2005:46:230-6.

17. Kamisaka Y, Kimura K, Uemura H, Shibakami M. Activation of diacylglycerol acyltransferase expressed in Saccharomyces cerevisiae: overexpression of Dga1p lacking the N-terminal region in the Deltasnf2 disruptant produces a significant increase in its enzyme activity. Appl Microbiol Biotechnol. 2010; 88:105-15.
18. Liu L, Shi X, Bharadwaj KG, Ikeda S, Yamashita H, Yagyu H, Schaffer JE, Yu $\mathrm{YH}$, Goldberg IJ. DGAT1 expression increases heart triglyceride content but ameliorates lipotoxicity. J Biol Chem. 2009;284:36312-23.

19. Kamisaka Y, Tomita N, Kimura K, Kainou K, Uemura H. DGA1 (diacylglycerol acyltransferase gene) overexpression and leucine biosynthesis significantly increase lipid accumulation in the Deltasnf2 disruptant of Saccharomyces cerevisiae. Biochem J. 2007:408:61-8.

20. Haili N, Louap J, Canonge M, Jagic F, Louis-Mondesir C, Chardot T, Briozzo $P$. Expression of soluble forms of yeast diacylglycerol acyltransferase 2 that integrate a broad range of saturated fatty acids in Triacylglycerols. PLoS One. 2016;11:e0165431.

21. Shockey JM, Gidda SK, Chapital DC, Kuan JC, Dhanoa PK, Bland JM, Rothstein SJ, Mullen RT, Dyer JM. Tung tree DGAT1 and DGAT2 have nonredundant functions in triacylglycerol biosynthesis and are localized to different subdomains of the endoplasmic reticulum. Plant Cell. 2006;18: 2294-313.

22. Rani SH, Krishna TH, Saha S, Negi AS, Rajasekharan R. Defective in cuticular ridges (DCR) of Arabidopsis thaliana, a gene associated with surface cutin formation, encodes a soluble diacylglycerol acyltransferase. J Biol Chem. 2010;285:38337-47.

23. Liu Q, Siloto RM, Snyder CL, Weselake RJ. Functional and topological analysis of yeast acyl-CoA:diacylglycerol acyltransferase 2, an endoplasmic reticulum enzyme essential for triacylglycerol biosynthesis. J Biol Chem. 2011:286:13115-26.

24. Cao H. Structure-function analysis of diacylglycerol acyltransferase sequences from 70 organisms. BMC Res Notes. 2011:4:249.

25. Cao H, Shockey JM, Klasson KT, Mason CB, Scheffler BE. Developmental regulation of diacylglycerol acyltransferase family gene expression in tung tree tissues. PLoS One. 2013;8:e76946.

26. Rani SH, Saha S, Rajasekharan R. A soluble diacylglycerol acyltransferase is involved in triacylglycerol biosynthesis in the oleaginous yeast Rhodotorula glutinis. Microbiology. 2013;159:155-66.

27. Saha S, Enugutti B, Rajakumari S, Rajasekharan R. Cytosolic triacylglycerol biosynthetic pathway in oilseeds. Molecular cloning and expression of peanut cytosolic diacylglycerol acyltransferase. Plant Physiol. 2006;141:1533-43.

28. Kalscheuer R, Steinbuchel A. A novel bifunctional wax ester synthase/acylCoA:diacylglycerol acyltransferase mediates wax ester and triacylglycerol biosynthesis in Acinetobacter calcoaceticus ADP1. J Biol Chem. 2003;278: 8075-82.

29. Rosli R, Chan PL, Chan KL, Amiruddin N, Low EL, Singh R, Harwood JL, Murphy DJ. In silico characterization and expression profiling of the diacylglycerol acyltransferase gene family (DGAT1, DGAT2, DGAT3 and WS/ DGAT) from oil palm, Elaeis guineensis. Plant Sci. 2018;275:84-96.

30. Yen $\mathrm{CL}$, Nelson DW, Yen MI. Intestinal triacylglycerol synthesis in fat absorption and systemic energy metabolism. J Lipid Res. 2015;56:489-501.

31. Harris CA, Haas JT, Streeper RS, Stone SJ, Kumari M, Yang K, Han X, Brownell N, Gross RW, Zechner R, Farese RV Jr. DGAT enzymes are required for triacylglycerol synthesis and lipid droplets in adipocytes. J Lipid Res. 2011; 52:657-67.

32. Cao H, Shockey JM. Comparison of TaqMan and SYBR green qPCR methods for quantitative gene expression in tung tree tissues. J Agric Food Chem. 2012:60:12296-303.

33. Cao H, Cao F, Klasson KT. Characterization of reference gene expression in tung tree (Vernicia fordii). Ind Crop Prod. 2013;50:248-55.

34. Cao H, Cao F, Roussel AM, Anderson RA. Quantitative PCR for glucose transporter and tristetraprolin family gene expression in cultured mouse adipocytes and macrophages. In Vitro Cell Dev Biol Anim. 2013;49:759-70.

35. Cao H, Polansky MM, Anderson RA. Cinnamon extract and polyphenols affect the expression of tristetraprolin, insulin receptor, and glucose transporter 4 in mouse 3T3-L1 adipocytes. Arch Biochem Biophys. 2007;459: 214-22.

36. Cao H, Urban JF Jr, Anderson RA. Cinnamon polyphenol extract affects immune responses by regulating anti- and proinflammatory and glucose transporter gene expression in mouse macrophages. J Nutr. 2008;138:83340.

37. Cao H, Urban JF Jr, Anderson RA. Insulin increases tristetraprolin and decreases VEGF gene expression in mouse 3T3-L1 adipocytes. Obesity (Silver Spring). 2008;16:1208-18.

38. Cao H, Sethumadhavan K, Bland JM. Isolation of cottonseed extracts that affect human Cancer cell growth. Sci Rep. 2018;8:10458. 
39. Cao H, Sethumadhavan K. Cottonseed extracts and gossypol regulate diacylglycerol acyltransferase gene expression in mouse macrophages. J Agric Food Chem. 2018;66:6022-30.

40. Jarvill-Taylor KJ, Anderson RA, Graves DJ. A hydroxychalcone derived from cinnamon functions as a mimetic for insulin in 3T3-L1 adipocytes. J Am Coll Nutr. 2001;20:327-36.

41. Cao H, Tuttle JS, Blackshear PJ. Immunological characterization of tristetraprolin as a low abundance, inducible, stable cytosolic protein. J Biol Chem. 2004;279:21489-99.

42. Bustin SA, Benes V, Garson JA, Hellemans J, Huggett J, Kubista M, Mueller R, Nolan T, Pfaffl MW, Shipley GL, Vandesompele J, Wittwer CT. The MIQE guidelines: minimum information for publication of quantitative real-time PCR experiments. Clin Chem. 2009;55:611-22.

43. Livak KJ, Schmittgen TD. Analysis of relative gene expression data using real-time quantitative PCR and the 2(-Delta Delta $C(T))$ method. Methods. 2001;25:402-8.

44. Han X, Lu M, Chen Y, Zhan Z, Cui Q, Wang Y. Selection of reliable reference genes for gene expression studies using real-time PCR in tung tree during seed development. PLoS One. 2012;7:e43084.

45. Mortazavi A, Williams BA, McCue K, Schaeffer L, Wold B. Mapping and quantifying mammalian transcriptomes by RNA-Seq. Nat Methods. 2008; 5:621-8.

46. Feng Y, Zhang L, Fu J, Li F, Wang L, Tan X, Mo W, Cao H. Characterization of glycolytic pathway genes using RNA-Seq in developing kernels of Eucommia ulmoides. J Agric Food Chem. 2016;64:3712-31.

47. Zeng $Y$, Tan $X$, Zhang $L$, Jiang N, Cao H. Identification and expression of fructose-1,6-bisphosphate aldolase genes and their relations to oil content in developing seeds of tea oil tree (Camellia oleifera). PLoS One. 2014;9:e107422.

48. Fan X, Yuan D, Tian X, Zhu Z, Liu M, Cao H. Comprehensive transcriptome analysis of Phytohormone biosynthesis and signaling genes in the flowers of Chinese chinquapin (Castanea henryi). J Agric Food Chem. 2017;65: 10332-49.

49. Scherer PE. Adipose tissue: from lipid storage compartment to endocrine organ. Diabetes. 2006;55:1537-45.

50. Wieser PB, Zeiger MA, Fain JN. Effects of dimethylsulfoxide on cyclic AMP accumulation, lipolysis and glucose metabolism of fat cells. Biochem Pharmacol. 1977:26:775-8.

51. Cases S, Stone SJ, Zhou P, Yen E, Tow B, Lardizabal KD, Voelker T, Farese RV Jr. Cloning of DGAT2, a second mammalian diacylglycerol acyltransferase, and related family members. J Biol Chem. 2001;276:38870-6.

52. Buhman KK, Smith SJ, Stone SJ, Repa JJ, Wong JS, Knapp FF Jr, Burri BJ, Hamilton RL, Abumrad NA, Farese RV Jr. DGAT1 is not essential for intestinal triacylglycerol absorption or chylomicron synthesis. J Biol Chem. 2002;277: 25474-9.

53. Chen Y, Zhou G, Wang Y, Xu L. F-BOX and oleosin: additional target genes for future metabolic engineering in tung trees? Ind Crop Prod. 2010;32:684-6.

54. GTEx Consortium. The genotype-tissue expression (GTEx) project. Nat Genet. 2013:45:580-5.

55. Mele M, Ferreira PG, Reverter F, DeLuca DS, Monlong J, Sammeth M, Young TR, Goldmann JM, Pervouchine DD, Sullivan TJ, Johnson R, Segre AV, Djebali S, Niarchou A, Wright FA, Lappalainen T, Calvo M, Getz G, Dermitzakis ET, Ardlie KG, Guigo R. Human genomics. The human transcriptome across tissues and individuals. Science. 2015;348:660-5.

56. Cao H, Chapital DC, Shockey JM, Klasson KT. Expression of tung tree diacylglycerol acyltransferase 1 in E. coli. BMC Biotechnol. 2011;11:73.

57. Cao H, Chapital DC, Howard OD Jr, Deterding LJ, Mason CB, Shockey JM, Klasson KT. Expression and purification of recombinant tung tree diacylglycerol acyltransferase 2. Appl Microbiol Biotechnol. 2012;96:711-27.

58. Weselake RJ, Madhavji M, Szarka SJ, Patterson NA, Wiehler WB, Nykiforuk CL, Burton TL, Boora PS, Mosimann SC, Foroud NA, Thibault BJ, Moloney MM, Laroche A, Furukawa-Stoffer TL. Acyl-CoA-binding and self-associating properties of a recombinant $13.3 \mathrm{kDa} \mathrm{N}$-terminal fragment of diacylglycerol acyltransferase-1 from oilseed rape. BMC Biochem. 2006;7:24

59. Chitraju C, Mejhert N, Haas JT, Diaz-Ramirez LG, Grueter CA, Imbriglio JE, Pinto S, Koliwad SK, Walther TC, Farese RV. Triglyceride synthesis by DGAT1 protects adipocytes from lipid-induced ER stress during lipolysis. Cell Metab. 2017:26:407-18.

60. Morrison S, McGee SL. 3T3-L1 adipocytes display phenotypic characteristics of multiple adipocyte lineages. Adipocyte. 2015;4:295-302.
61. Carballo E, Lai WS, Blackshear PJ. Feedback inhibition of macrophage tumor necrosis factor-alpha production by tristetraprolin. Science. 1998;281:1001-5.

62. Carballo E, Lai WS, Blackshear PJ. Evidence that tristetraprolin is a physiological regulator of granulocyte-macrophage colony-stimulating factor messenger RNA deadenylation and stability. Blood. 2000;95:1891-9.

63. Phillips K, Kedersha N, Shen L, Blackshear PJ, Anderson P. Arthritis suppressor genes TIA-1 and TTP dampen the expression of tumor necrosis factor alpha, cyclooxygenase 2, and inflammatory arthritis. Proc Natl Acad Sci U S A. 2004;101:2011-6.

64. Taylor GA, Carballo E, Lee DM, Lai WS, Thompson MJ, Patel DD, Schenkman DI, Gilkeson GS, Broxmeyer HE, Haynes BF, Blackshear PJ. A pathogenetic role for TNF alpha in the syndrome of cachexia, arthritis, and autoimmunity resulting from tristetraprolin (TTP) deficiency. Immunity. 1996;4:445-54.

65. Sauer I, Schaljo B, Vogl C, Gattermeier I, Kolbe T, Muller M, Blackshear PJ, Kovarik $P$. Interferons limit inflammatory responses by induction of tristetraprolin. Blood. 2006;107:4790-7.

\section{Ready to submit your research? Choose BMC and benefit from:}

- fast, convenient online submission

- thorough peer review by experienced researchers in your field

- rapid publication on acceptance

- support for research data, including large and complex data types

- gold Open Access which fosters wider collaboration and increased citations

- maximum visibility for your research: over $100 \mathrm{M}$ website views per year

At BMC, research is always in progress.

Learn more biomedcentral.com/submissions 